\title{
ДОСВІД ТА ПЕРСПЕКТИВИ ЗАСТОСУВАННЯ КАРБОКСІТЕРАПІЇ ПРИ ЦУКРОВОМУ ДІАБЕТІ
}

\author{
Дроговоз С. М. ${ }^{1}$, Белік Г. В. ${ }^{1}$, Калько К. О. ${ }^{1}$, Шевченко С. I. ${ }^{2}$, \\ Дерімедвідь Л. В. ${ }^{1}$, Кіреев І. В. ${ }^{1}$, Штробля А. Л. ${ }^{3}$ \\ ${ }^{1}$ Національний фбарлацевтичний університет, м. Харків, Украйна \\ ${ }^{2}$ Харківський національний медичний університет, \\ м. Харків, Украӥна \\ ${ }^{3}$ Ужгородський національний університет, м. Ужгород, Україна
}

В останній час наявність великого обсягу знань з патогенезу цукрового діабету (ЦД) та його сучасних терапевтичних можливостей не сприяють поліпшенню метаболічного контролю даного захворювання та не можуть завжди гарантувати ефективність терапії ЦД, тому оптимізація лікування даного захворювання за рахунок альтернативних методів фармакотерапії є актуальною медичною та соціальною проблемою $[1,2,3]$. Разом з тим патогенетичні механізми ЦД в значній мірі пов’язані з процесом вільнорадикального окиснення (BРО) $[4,5,6]$. Сьогодні порушення даного процесу розглядають як універсальний біохімічний механізм, який об'єднуе основні ланки токсичного впливу гіперглікемії на організм. Тому в теперішній час для лікування ЦД використовують протидіабетичні препарати, формакодинаміка яких не обмежуеться тільки гіпоглікемічною дією, а ще дозволяе позитивно впливати одночасно на декілька патогенетичних ланок та прогноз даного захворювання, на якість та тривалість життя пацієнта $[7,8]$.

За останні 10 років впроваджена велика кількість нових сучасних технологій у медицині, так, карбоксітерапія стала широко off label (поза інструкціею та протоколом лікування) застосовуватися для лікування ЦД та його ускладнень $[9,10]$. Вуглекислий газ $є$ активним антиоксидантом і ці властивості особливо проявляються при його фізіологічних концентраціях в крові: $\mathrm{CO}_{2}$ здатний попереджати пошкодження активними формами кисню клітин міокарду, судин, слизової оболонки шлунку та кишківника, елементів крові [11]. Отже, при фiзіологічній гіперкапнії $\mathrm{CO}_{2}$ гальмуе реакції утворення активних форм кисню, захищаючи таким чином клітини організму від руйнування: $\mathrm{CO}_{2}$, зв'язуючи іони водню, блокуе швидкість окислювальних реакцій [11]. Згідно з дослідженнями, вуглекислий газ пригнічуе генерацію активних форм кисню $($ АФК) не тільки в фагоцитах крові і аль-

\footnotetext{
* Автори гарантують колективну відповідальність за все, що опубліковано в статті.

Автори гарантують відсутність конфлікту інтересів та власної фінансової зацікавленості при написанні статті.

Рукопис надійшов до редакції 24.06.2021.
} 
веолярних макрофрагах, а й в клітинах тканин внутрішніх органів і в тому числі в підшлунковій залозі. Цей ефект $\mathrm{CO}_{2}$ підтверджений на семи видах фагоцитуючих клітин (фагоцитах крові, альвеолярних макрофрагах, тканинних фрагоцитах: макрофрагах печінки, нирок, мозку, легенів, шлунка), на шести видах тканинних клітин внутрішніх органів (печінки, мозку, серця, легенів, нирок, скелетних м'язів). Крім того, при прямому впливі вуглекислий газ здатний пригнічувати генерацію АФК мітохондрій $[1,10]$.

Отже, вуглекислий газ, будучи універсальним інгібітором генерації активних форм кисню (вільних радикалів), проявляе супероксидінгібуючу дію, що сприяе суттевому полегшенню стану хворих на ЦД за рахунок вазодилятації, посилення оксигенації, антигіпоксичних, антиоксидантних та протизапальних процесів, що сприяє допоміжній та альтернативній терапії ЦД $[12,13,14]$.

Ефективність зовнішнього дихання визначається за рівнем вуглекислого газу в альвеолах (6,5 \%) та в крові (7-7,5\%). Такі концентрації $\mathrm{CO}_{2} є$ абсолютно необхідною умовою нормального проходження усіх біохімічних, гуморальних та тканинних процесів у тому числі і в підшлунковій залозі $[10,15,16]$. У хворих, що страждають на ЦД, в умовах стійкої гіпоксії відбувається роз'єднання біохімічного процесу окисного фоосфорилювання, що супроводжується серйозними проявами тканинної гіпоксії [15], тоді як вуглекислий газ можна вважати «вартовим», що сигналізує про небезпеку гіпоксії [9].

Головним ускладненням ЦД є діабетична ангіопатія [17]. При тривалому перебігу ЦД підвищення рівня глюкози в крові, призводить до пошкоджень всіх судин організму: їх стінки починають деформуватися, що призводить до порушення їх функції і перешкоджає нормальному току крові, надходженню поживних речовин та кисню до всіх клітин та тканин організму. В результаті починається кисневе голодування тканин та відбувається порушення фрункції внутрішніх органів, в тому числі підшлункової залози (ПЗ) [18]. Однак встановлено, що вуглекислий газ підвищує ступінь тканинного дихання та процеси фосфорилювання, які порушені при патологічних процесах в клітині $[13,16]$.

Пошкодження дрібних судин при ЦД (мікроангіопатія) характеризуеться пошкодженням базальної мембрани та проліфрерацією ендотелію. Ідентичні порушення мікроциркуляції зустрічаються в судинах сітківки (ретинопатія) і капілярах клубочка нирок (нефропатія). Зазначені розлади мікроциркуляції відіграють важливу роль в патогенезі ЦД, так як виникають при цьому трофічні порушення в тканинах ПЗ, що призводить до прогресування даного захворювання [19].

У дослідженнях Zbroja H. зі співавторами методом лазерного доплерівського пікфлуометра проведено аналіз параметрів, що відображають характер змін мікроциркуляції у пацієнтів, хворих на ЦД, після сухих вуглекислих ванн. Авторами виявлено статистично достовірне збільшення під дією сухих $\mathrm{CO}_{2}$-ванн таких показників: рівня мікроциркуляції на 28,3 \%, індексу флаксмоцій, що характеризуе ефрективність регуляції кровотоку в системі мікроциркуляції при набряках, на 36,8 \%, амплітуди низькочастотних коливань на 13,9 \% та зменшення амплітуди пульсових ритмів на 23,2 \%. Також відзначено, що під впливом $\mathrm{CO}_{2}$-ванн відбувається зниження резерву капілярного кровотоку на 13,3 \%, 3 достовірним збільшенням на 68,9 \% часу напіввідновлення капілярного кровотоку і його швидкості, щільності капілярної сітки, зменшення кількості ліпідних включень, тривалості стазу, кількості сладжів i розмірів периваскулярної зони до нормальних показників [20].

Ще одним механізмом позитивної дії вуглекислого газу на патологічні процеси в організмі хворих, що страждають на ЦД, $\epsilon$ едрект Вериго-Бора [10]. Завдяки цьому ефректу терапія вуглекислим газом дозволяе зменшити ступінь виразності порушень мікроциркуляції $\mathrm{O}_{2}$ в тканинах, в тому числі у ПЗ. Аналіз показників кінетики кисневого метаболізму у пацієнтів з ЦД з інгібованими процесами тканинного дихання показав зниження критичної кон- 
центрації кисню на 11,7 \%, а після застосування сухих вуглекислих ванн відзначалося підвищення фрункціональних резервів дихальних ферментів на 14,4 \%. Крім того, спостерігалося зниження коефіцієнта кисневого резерву на 18,5 \%. Це вказує, що в результаті дії $\mathrm{CO}_{2}$ виникає покращення співвідношення процесів доставки та споживання кисню тканинами [9]. Таким чином, при збільшені $\mathrm{CO}_{2}$ в організмі посилюється вивільнення кисню, що приводить до покращення оксигенації тканин, а також активного мікроциркуляторного розширення судин та поліпшення кровотоку в капілярних артеріолах. Розширення судин, в тому числі коронарних, та зниження артеріального тиску (AT) при введенні $\mathrm{CO}_{2}$ відбувається внаслідок його прямої дії на рецептори гладко-м'язового волокна артеріол і вивільнення вазоактивних сполук: гістаміну, ацетилхоліну, серотоніну та кінінів [9].

ЦД характеризуеться стійким рівнем підвищення АT, а також порушенням діастолічної функції лівого шлуночка [20, 21]. У таких хворих після комплексного лікування із застосуванням сухих вуглекислих ванн достовірно збільшувався середній показник співвідношення піків раннього та пізнього наповнення лівого шлуночка (близько на 10 \%). При проведенні неінвазивної $\mathrm{CO}_{2}$-терапії (ванни) у хворих на ЦД спостерігалося поліпшення об'ємних параметрів внутрішньосерцевої гемодинаміки та зниження загального периферичного опору судин особливо при збільшенні фpiзичної працездатності [22]. Отримані позитивні результати впливу сухих вуглекислих ванн на показники діастолічної функції лівого шлуночка, заслуговують на увагу в комплексі профілактичних заходів при артеріальній гіпертензії та ЦД [9].

При аналізі результатів ліпідограми у пацієнтів з синдромом метаболічних порушень з різними дисліпідеміями, які використовували сухі вуглекислі ванни, була виявлена тенденція до підвищення ліпопротеїдів високої щільності та зниження кількості ліпопротеїдів низької і дуже низької щільності. Після застосування сухих вуглекислих ванн у цих пацієнтів виявлено тенденцію до зниження показників загального холестеролу і коефіцієнту атерогенності [11]. Тому виражені ваготонічний та вазодилятуючий ефекти, позитивний вплив на ліпідний обмін сухих вуглекислих ванн можуть використовуватися в комплексі гіпотензивної та антиатеросклеротичної терапії при ЦД. Крім того, при дослідженні інтенсивності процесів (ПОЛ) та антиоксидантної активності організму методом індукованої біохемілюмінесценції було виявлено, що після сухих вуглекислих ванн відбувається активація антиоксидантної системи, про що свідчило зниження на 21,2 \% вмісту в плазмі крові вільних радикалів, достовірне зниження показника малонового диальдегіду на 11,9 \%, збільшення активності каталази еритроцитів на 6,5 \%, а також була виявлена тенденція до зниження дієнових кон'югатів [23].

При важких формах ЦД спостерігається необоротне глікозилювання антиоксидантних ферментів, таких як каталаза та супероксиддисмутаза, з подальшою їх інактивацією, що сприяе наростанню ВРО-уражень клітин підшлункової залози [9]. Крім того, у хворих на ЦД відзначається підвищення в мембранах еритроцитів малонового диальдегіду - одного 3 маркерів процесу ПОЛ. В той же час, окислювальний стрес при ЦД порушує реологічні властивості крові з розвитком гемостазу та тромбозу, активує експресію молекулярних клітин адгезії, що регулюють взаємодію між ендотеліальними клітинами і лейкоцитами $[24,25]$.

При гіперглікемії виникає неферментативне глікозилювання білків з утворенням проміжної сполуки: продуктів Амадорі [26]. Надалі це призводить до підвищення проникності та зниження еластичності судин, зміни фрункції ензимів, обміну ліпопротеїнів та вільних жирних кислот. Отже, дефіцит інсуліну при ЦД проявляеться порушеннями всіх видів обміну речовин, з яких порушення вуглеводного обміну найбільш виразні. Ступінь порушення вуглеводного обміну відображає рівень глікозильованого гемоглобіну (НвA1c), так як порушення метаболізму глюкози веде до глікозилювання білків, що сприяє утворенню кінцевих 
продуктів глікозилювання, які вважаються найважливішими медіаторами мікро- та макроангіопатії на пізніх стадіях ЦД [27].

Клінічні спостереження показали, що застосування карбоксітерапї у вигляді сухих $\mathrm{CO}_{2}$-ванн не тільки сприяло зниженню глікемії натще, а й нормалізуе вплив на показники глікозильованого гемоглобіну та глюкози при проведенні постпрандіального тесту. Симптоматичний позитивний ефект карбоксітерапії проявлявся в зниженні показників гіперглікемії, почуття спраги, симптомів поліурії, свербіння шкіри, слабкості [28]. Сухі вуглекислі ванни стимулюють антистресові системи, усувають дисбаланс вегетативної регуляції та підвищують неспецифічну резистентність та адаптаційні можливості організму, що особливо важливо для пацієнтів з дисциркуляторною енцефалопатією внаслідок ураження дрібних судин при ЦД [29].

Отже, вуглекислі ванни мають великий арсенал позитивних метаболічних едектів, які надають універсальний вплив на перебіг патологічних процесів при ЦД.

Для підтвердження ефрективності карбоксітерапії при лікуванні «діабетичної стопи» були проведені клінічні дослідження [30]. Так, в Al-Ahliyya Amman University Йорданії було проведено дослідження з метою оцінки стану пацієнтів з ЦД та синдромом діабетичної стопи при застосуванні $\mathrm{CO}_{2}$-терапії. Для цього проводились щоденні підшкірні сеанси ін'єкційної карбоксітерапії. Вплив $\mathrm{CO}_{2}$-терапії на синдром діабетичної стопи оцінено за допомогою доплерівського дослідження стану судин. Ефективність $\mathrm{CO}_{2}$-терапії проводили за такими показниками: надходження крові до периферичних судин ніг; розміром та ступенем кровопостачання ураженої області; кольору тканин, а також суб'єктивними відчуттями пацієнта в стопі (табл.).

Після проведення щоденних сеансів карбоксітерапії протягом двох тижнів відзначалося поліпшення кровотоку в області ураженої стопи та кольору шкіри, зниження больових відчуттів за рахунок поліпшення оксигенації тканин, виникнення гіперкапнії, яка приводила до збільшення кисневого обміну між гемоглобіном крові та міоглобіном м'язів периферичних тканин, розширення судин в шкірі та м’язах за рахунок зниження рН та інших ефектів карбоксітерапії [1, 7].

Отже, терапія $\mathrm{CO}_{2}$ сприяє збільшенню кисневого обміну між гемоглобіном крові та міоглобіном периферичних тканин, викликає зміни тонусу артерій в шкірі та м'язах, які розширюються за рахунок зниження $\mathrm{pH}$ крові, а зміна рН сприяе тому, що гемоглобін стає більш ефективним транспортером $\mathrm{O}_{2}[10,13]$.

Також встановлено, що введення $\mathrm{CO}_{2}$ в організм викликало вивільнення фрактору росту ендотелію для поліпшення ангіогенезу, що дозволило посилити оксигенацію тканин, а завдяки антибактеріальним властивостям $\mathrm{CO}_{2}$ зменшувався розвиток аеробної фрлори в ураженій ділянці стопи. Про поліпшення кровообігу тканин нижніх кінцівок свідчили позитивні зміни кольо-

\section{Результати вимірювання параметрів до і після сеансів карбоксітерапії при лікуванні діабетичної стопи}

\begin{tabular}{|c|c|c|}
\hline \multicolumn{2}{|l|}{ Параметри } & Значення \\
\hline \multirow{2}{*}{$\begin{array}{l}\text { Доплеровське дослідження, мм } \\
\text { (величина просвіту судин) }\end{array}$} & до & $9,81 \pm 1,11$ \\
\hline & після & $13,77 \pm 1,01$ \\
\hline \multirow{2}{*}{ Розмір виразкової області, см } & до & $3,18 \pm 0,40$ \\
\hline & після & $3,00 \pm 0,38$ \\
\hline \multirow{2}{*}{$\begin{array}{c}\text { Колір шкірного покриву, бали } \\
(0-\text { синюшність, } 10 \text { - гіперемія) }\end{array}$} & до & $4,18 \pm 0,17$ \\
\hline & після & $3,36 \pm 0,27$ \\
\hline \multirow{2}{*}{ Суб'єктивні відчуття пацієнта, бали } & до & $4,36 \pm 0,15$ \\
\hline & після & $3,45 \pm 0,23$ \\
\hline
\end{tabular}


ру шкіри в ділянці уражень та загоєння уражених дефектів стоп (табл.). Крім того, суб'єктивні відчуття пацієнтів з синдромом діабетичної стопи в ході $\mathrm{CO}_{2}$-терапії також покращилися за рахунок протизапальної, антиоксидантної та знеболюючої дії $\mathrm{CO}_{2}$ [16]. Останнє було пов'язане з впливом $\mathrm{CO}_{2}$ на посилення синтезу ендорфінів, стимуляцію аферентної інервації (зони Захар'їнаГеда, тригерних точок), що відповідно викликало в ЦНС позитивну рефлекторну еферентну реакцію на сегментарно розташовані органи. В результаті цих ефектів карбоксітерапії відбувалося зменшення больової чутливості в зоні гіпералгії (діабетичного ураження шкіри) (табл.) [31].

Таким чином, наведені дані свідчать про раціональність застосування карбоксітерапії як альтернативного off label методу лікування ЦД та його ускладнень. Також, узагальнено основні переваги карбоксітерапії при ЦД, які наведені нижче [11]:

1. Це фозіологічний метод лікування, який підвищуе та відновлюе енергетичний потенціал клітин організму.

2. Безпечний метод, так як вводиться не чужорідна речовина, а вуглекислий газ, який є природним учасником біохімічних процесів в організмі. Вуглекислий газ вводиться в дозі в десять разів меншій, ніж утворюеться в організмі при інтенсивному фізичному навантаженні.
3. Безпека методу при використанні медичного $\mathrm{CO}_{2}$ гарантована використанням систем, сертифікованих в Свропі, США, Україні та в багатьох інших країнах.

4. Даний метод відрізняеться відсутністю алергічних реакцій, нейро-, нефро-, гепато- та гастротоксичності.

5. Карбоксітерапія застосовується більше 50 років без будь-яких ускладнень при діабетичної стопі, ЦД та інших захворюваннях.

6. Цей метод може бути застосований в амбулаторних умовах в будь-який час року.

7. Виражений протизапальний та протимікробний ефекти карбоксітерапії выключають ризик інфікування та запальних реакцій на місці ін'єкції.

8. Карбоксітерапія може застосовуватися у виді монотерапії, а також поєднуватися з іншими видами лікування.

9. 3 метою посилення впливу вуглекислого газу та виключення гідростатичного тиску води на поверхню тіла застосовують «сухі» вуглекислі вани, які добре переносяться хворими з ЦД та розширюють показання до застосування карбоксітерапії.

10. Терапевтичний ефект від застосування даного методу часто спостерігається вже після 1-2 процедур, а через три тижні виявляє максимальний едект.

\section{ЛITEРАТУРA \\ (REFERENCES)}

1. Schmidt AM. Arterioscler Thromb Vasc Biol 2019;39(4): 558-568. https://doi.org/10.1161/ATVBAHA.119.310961.

2. da Rocha RB, Silva CS, Cardoso VS. Curr Diabetes Rev 2020;16(6): 598-607. https://doi.org/10.2174/1573399815 666190702161849 .

3. Kalra S, Chaudhary S. J Pak Med Assoc 2019;69(9): 1394-1395.

4. Singh R, Devi S, Gollen R. Diabetes Metab Res Rev 2015;31(2): 113-126. https://doi.org/10.1002/dmrr.2558. PMID: 24845883.

5. Gadjeva VG, Goycheva P, Nikolova G, Zheleva A. Adv Clin Exp Med 2017;26(8): 1237-1243. https://doi. org/10.17219/acem/68988.

6. Poblete-Aro C, Russell-Guzmán J, Parra P, et al. Rev Med Chil 2018;146(3): 362-372. https://doi.org/10.4067/ s0034-98872018000300362.
7. Wei JP, Wang QH, Zheng HJ, Wei F. Chin J Integr Med 2018; 24(10): 723-727. https://doi.org/10.1007/s11655018-2844-2.

8. American Diabetes Association. Diabetes Care 2018; 41(Suppl 1): S38-S50. https://doi.org/10.2337/dc18-S004. PMID: 29222375.

9. Drogovoz SM, Bunjatjan ND. Voprosy kurortologii, fizioterapii i lechebnoj fizicheskoj kul'tury 2018;95(5): 72-76.

10. Kalko KO, Drogovoz SM, Komarova AP, et al. Pharmacology online 2021;3: 179-186, available at: https:// pharmacologyonline.silae.it/files/archives/2021/vol1/ PhOL_2021_1_A024_Kalko.pdf

11. Drogovoz SM, Kalko KO, Hailat IA, et al. Pharmacology online 2021;3: 447-455, available at: https://pharmacologyonline.silae.it/files/archives/2021/vol1/ PhOL_2021_1_A051_Drogovoz.pdf 
12. Zelenková H. Glob Dermatol 2017;4(1): 1-5 https://doi. org/10.15761/GOD.1000202.

13. Drogovoz SM, et al. Farmakologija i lekarstvennaja toksikologija 2016;6(51): 12-20.

14. Zelenkova H. J Clin Cell Immunol 2016;7(5): 33.

15. Xi L, Chow CM, Kong X. J Diabetes Res 2016;2016: 1527852. https://doi.org/10.1155/2016/1527852.

16. Drogovoz SM, et al. Racional'naja farmakoterapija 2016;1: 37-39.

17. Feldman EL, Callaghan BC, Pop-Busui R, et al. Nat Rev Dis Primers 2019;5(1): 42. https://doi.org/10.1038/ s41572-019-0097-9.

18. Dewanjee S, Das S, Das AK, et al. Eur J Pharmacol 2018;833: 472-523. https://doi.org/10.1016/j.ejphar.2018. 06.034 .

19. Zeng Y, Cao D, Yu H, et al. Br J Ophthalmol 2019; 103(12): 1747-1752. https://doi.org/10.1136/bjophthalmol-2018-313582.

20. Zbroja H, Kowalski M, Lubkowska A. Int J Environ Res Public Health 2021;18(4): 1490. https://doi.org/10.3390/ ijerph18041490.

21. Cryer MJ, Horani T, DiPette DJ. J Clin Hypertens (Greenwich) 2016;18(2): 95-100. https://doi.org/10.1111/ jch.12638.

22. Pagourelias ED, Zorou PG, Tsaligopoulos M, et al. Int $J$ Biometeorol 2011;55(5): 657-663. https://doi.org/10.1007/ s00484-010-0380-7.
23. Kotenko KV, Esipov AV, Yamenskov VV. Voen Med Zh 2016;337(9): 32-37.

24. França EL, Ribeiro EB, Scherer EF, et al. Biomed Res Int 2014; 2014: 840379. https://doi.org/10.1155/ $2014 / 840379$.

25. Gabunia T, Turabelidze-Robaqidze S, Sujashvili R, et al. Georgian Med News 2015;(248): 39-45.

26. Gabreanu GR, Angelescu S. Discoveries (Craiova) 2016; 4(2): e60. https://doi.org/10.15190/d.2016.7.

27. Sawada S, Tsuchiya S, Kodama S, et al. Diabetes Res Clin Pract 2020; 165: 108240. https://doi.org/10.1016/j. diabres.2020.108240.

28. Hussain J, Cohen M. Evid Based Complement Alternat Med 2018;2018: 1857413. https://doi.org/10.1155/ $2018 / 1857413$

29. Gerasimenko EN, Meshchaninov VN, Zvezdina EM, et al. Adv Gerontol 2014;27(3): 477-483.

30. Shalan N, Al-Bazzaz A, Al-Ani I, et al. J Diab Mellitus 2015; 5(4): 284-289. https:/doi.org/10.4236/ jdm.2015.54035.

31. Kenichi Otsuguro, Sumiko Yasutake, Yoshihiko Yamaji, et al. Jap Soc Alternat Animal Experim 2008;14:101106.

\title{
ДОСВІД ТА ПЕРСПЕКТИВИ ЗАСТОСУВАННЯ КАРБОКСІТЕРАПІЇ ПРИ ЦУКРОВОМУ ДІАБЕТІ
}

\author{
Дроговоз С. М. ${ }^{1}$ Белік Г. В. ${ }^{1}$, Калько К. О. ${ }^{1}$, Шевченко С. I. ${ }^{2}$, \\ Дерімедвідь Л. В. ${ }^{1}$, Кіреев І. В. ${ }^{1}$ Штробля А. Л. ${ }^{3}$ \\ ${ }^{1}$ Національний фбармацевтичний університет, м Харків, Україна \\ ${ }^{2}$ Харківський національний медичний університет, м. Харків, Україна \\ ${ }^{3}$ Ужгородський національний університет, м. Ужгород, Украӥна
}

Цукровий діабет (ЦД) є глобальною актуальною соціальною проблемою XXI століття.

Метою даного огляду літератури: $е$ аналіз фізіологічних властивостей та фармакотерапевтичних можливостей карбоксітерапії, а також досвіду застосування даного методу для лікування ЦД.

Матеріали і методи дослідження. Наукові публікації в зарубіжних та вітчизняних журналах переважно за останні 5 років, інтернет ресурси по карбоксітерапії як методу лікування ЦД.

Результати досліджувати і їх обговорення. Вуглекислий газ будучи універсальним інгібітором генерації активних фрорм кисню (вільних радикалів), проявляе супероксидінгібуючу дію, що сприяе суттєвому полегшенню стану хворих на ЦД за рахунок вазодилятації, посилення оксигенації, антигіпоксичних, антиоксидантних та протизапальних процесів, що сприяе допоміжній та альтернативній терапії ЦД. В результаті аналізу літератури були зіставленні механізми реалізації фрармакологічних ефектів карбоксітерапії з окремими ланками патогенезу ЦД. Клінічні спостереження показали, що застосування карбоксітерапії у вигляді сухих $\mathrm{CO}_{2}$-ванн не тільки сприяло зниженню глікемії натще, а й нормалізуе вплив на показники глікозильованого гемоглобіну та глюкози при проведенні постпрандіального тесту. Симптоматичний позитивний едект карбоксітерапії проявлявся в зниженні показників гіперглікемії, почуття спраги, симптомів поліурії, свербіння шкіри, слабкості. Проаналізовані механізми і ефекти карбоксітерапії, представлені дані свідчать про раціональність застосування карбоксітерапії як альтернативного методу лікування ЦД та його ускладнень.

Висновки. 3 огляду на сучасні можливості фрармакотерапії ЦД, більш ніж п’ятдесятирічний досвід застосування карбоксітерапії в практичній медицині дозволяє рекомендувати цей метод як альтернативну off-label терапію ЦД.

К лючові слов а: цукровий діабет, лікування, карбоксітерапія. 


\section{EXPERIENCE AND PROSPECTS OF CARBOXYTHERAPY IN DIABETES MELLITUS}

S. M. Drogovoz ${ }^{1}$, G. V. Belik ${ }^{1}$, K. O. Kalko ${ }^{1}$, S. I. Shevchenko ${ }^{2}$, L. V. Derymedvid ${ }^{1}$, I. V. Kireyev ${ }^{1}$, A. L. Shtroblya ${ }^{2}$

${ }^{1}$ National University of Pharmacy, Kharkiv, Ukraine

${ }^{2}$ Kharkiv National Medical University, Kharkiv, Ukraine

${ }^{3}$ Uzhgorod National University, Uzhgorod, Ukraine

Diabetes mellitus (DM) is a global topical social problem of the XXI century.

The aim of this literature review is to analyze the physiological properties and pharmacotherapeutic possibilities of carboxytherapy, as well as the experience of this method for the treatment of diabetes.

Materials and methods. Scientific publications in foreign and domestic journals mainly for the last 5 years, online resources on carboxytherapy as a method of DM treating.

Results and discussions. Carbon dioxide, as an universal inhibitor of the generation of reactive oxygen species (free radicals), has a superoxide-inhibitory effect, which contributes to a significant relief of the condition of patients with diabetes due to vasodilation, increased oxygenation, antihypoxic, antioxidant and anti-inflammatory processes, which promotes auxiliary and alternative therapy of diabetes. As a result of the literature analysis, the mechanisms of implementation of the pharmacological effects with separate links of the pathogenesis of diabetes were compared. Clinical observations have shown that the use of carboxytherapy in the form of dry $\mathrm{CO} 2$ baths not only contributed to a decrease in fasting glycemia, but also normalizes effect on the parameters of glycosylated hemoglobin and glucose indicators during the postprandial test. The symptomatic positive effect of carboxytherapy was manifested in a decrease in hyperglycemia, thirst, symptoms of polyuria, itchy skin and weakness. The mechanisms and effects of carboxytherapy as an effective alternative method for treating diabetes mellitus and its complications have been analyzed. The presented data indicate the rational use of carboxytherapy as an alternative method for treating diabetes and its complications.

Conclusions. Given the current possibilities of pharmacotherapy of diabetes and more than fifty years of experience in the use of carboxytherapy in practical medicine allows us to recommend this innovative method as an alternative to off-label therapy of diabetes.

Key words: diabetes mellitus, treatment, carboxytherapy.

Дроговоз С. М.

ORCID ID 0000-0002-9997-2197

Белік Г. В.

ORCID ID 0000-0001-7207-2036

Калько К. О.

ORCID ID 0000-0002-8776-477X

Шевченко С. I.

ORCID ID 0000-0001-8925-3511

Деріледвідь Л. В.

ORCID ID 0000-0002-5064-6550

Кіресв I. B.

ORCID ID 0000-0002-5413-9273

Штробля А. Л.

ORCID ID 0000-0002-9499-4880 